\title{
Wild Performatives: experiments in rewilding at the Knepp Wildland Project
}

\author{
David Overend and Jamie Lorimer
}

\begin{abstract}
This article reflects on a two-day creative workshop at Knepp Castle Estate in October 2017. Knepp is the location of a large-scale 'rewilding' project established in 2002, which uses free-roaming herbivores to cultivate habitat change and restore natural processes. Using collaborative performance-making strategies, participants attempted to respond and contribute to the complex ecology of the site, exploring the potential for productive exchanges between human and nonhuman actors. The article focusses on a series of 'wild performatives' that occurred during the event. Focussing on three applications of this concept, it explores a range of affective encounters with the ecologies, practices and concepts of rewilding.
\end{abstract}

Conservation, Knepp, Performance, Rewilding, Transdisciplinarity

\section{Introduction}

This article emerges from 'Performing Wild Geographies'; a two-day creative workshop that took place at the Knepp Castle Estate in West Sussex in October 2017. The Estate is home to the Knepp Wildland Project, a large-scale conservation initiative established in 2002 by the landowners, Sir Charles Burrell and Isabella Tree. Knepp is a former dairy farm, whose fields have been gradually taken out of production in favour of 'a "process-led", non-goalorientated project where, as far as possible, nature takes the driving seat' (Knepp Wildland, online). Populations of 'hardy' breeds of domesticated large herbivores (Old English longhorn cattle, Exmoor ponies and Tamworth pigs), were introduced and are allowed to roam freely alongside non-native fallow deer, and native roe and red deer. They are encouraged to generate a 'naturalistic' grazing regime that will foster habitat change. The project is informed by the model of grazing ecology promoted by the Dutch paleoecologist Frans Vera (Vera 2000). Knepp represents a specific version of 'rewilding', an approach to nature conservation that is gaining prominence in scientific and policy circles, and in popular culture (Lorimer et al. 2015; Svenning et al. 2016; Monbiot 2013).

Insert Figure 1: a warning sign at the border of Knepp Wildland

Performing Wild Geographies aimed to explore ecologies, performances and conceptualisations of rewilding through a transdisciplinary collaboration on site at Knepp. 
This event was the starting point of an ongoing project led by Jamie Lorimer (Geography, University of Oxford); David Overend (Drama, Theatre and Dance, Royal Holloway, University of London (RHUL)); and Danielle Schreve (Quaternary Science, RHUL). Our aim is to animate specialist knowledge of Quaternary faunal history (the last 2.6 million years), through a creative sensibility open to innovative futures in wildlife conservation, in order to challenge how contemporary publics might engage with wildness. To this end, we recruited a 16-strong group of theatre practitioners/scholars, human geographers, palaeoecologists, conservationists, visual artists, and journalists. All were involved in a series of presentations, walks, workshops and discussions, joined at various points by Burrell and Tree, along with Knepp's resident ecologist, Penny Green. These structured activities and field experiments mobilised exchanges of knowledge, practice and experience across disciplines. The wild ecologies of Knepp catalysed collaborations on a range of scales, leading to a provisional route map for further research in trandisciplinarity and on the prospects of rewilding. As our collboration travels beyond Knepp to explore other examples and applications of rewilding, this document will serve as an important practical and conceptual framework, open to continual interrogation and modification as the project evolves.

This article focusses on a series of 'wild performatives' that occurred during the event. This term refers to affective encounters with wildlife that make an intervention into the sphere of relations between human and nonhuman actors. The term 'performative' has been widely debated since J.L. Austin proposed that certain speech acts transcend their significatory function to have an immediate impact on their environment (Austin 1962). While the concept has continued to influence critical perspectives on the efficacy of cultural practices (von Hantelmann 2010), two important conceptual modifications have been proposed. First, Jacques Derrida rejected the idea that the 'doing' of the performative utterance can be located in the present moment of the act (Derrida 1972). Rather, Derrida emphasised the citational premise of meaning-generation and its reliance on the iterability of recognisable forms. In this perspective, performatives are founded on a history of repetitions, and make recourse to the learned systems through which they derive their meaning. Second, much contemporary debate on performativity has responded to Judith Butler's influential work on the construction and signification of gender (Butler 1990), focusing on the complex ways in which we mark our identities through performance (Dolan 2001). This theory reveals 'manifestations and enactments of identity and belonging' as socially determined, and predicated on contestable and unresolvable conventions (Madison and Hamera 2006, xviii). 
Derrida and Butler's formulations pose particular challenges when it comes to applying performativity to our exchanges with other species. We are mindful that our interactions with wildlife are determined by various cultural conventions and constructions of identity. However, the dialogical exchange implied in interhuman performatives requires a more openended, creative and exploratory dynamic when nonhuman actants are involved. A more-thanhuman model of performativity is needed that is not wholly reliant on learned or shared exchanges, and is not solely initiated through human agency (Thrift 2007). Such experimental and unruly acts would ideally take place through unpredictable encounters in unexpected places. They would require us to be open to the environment and alert to entanglements with nonhuman phenomena of many kinds: receptive to chance and perceptive of change.

The rest of this article outlines three possible applications of the concept of wild performatives. In the first instance are situations in which human participants seek to attune to and enact dimensions of the wild. The aim is 'learning to be affected' (after (Despret 2004) by the nonhuman inhabitants, processes and forces within a site. Learning to be affected involves practices of bodily calibration, developing and using unfamiliar senses, sometimes assisted by technologies. Here, a wild performative is akin to the ecological practices of fieldwork or the archaeological practices of assemblage (Pearson and Shanks 2001), which help scientists understand past and present rhythms of a location or habitat. Considering such practices as part of an ecological assemblage prompts a greater awareness of the coexistence and interrelatedness of individuals within a wider ecology. Such activities might involve researchers becoming-animal, becoming-plant, or even becoming-dirt in search of a better understanding of the lived or material experience of the focal nonhuman (Lorimer 2008). Popular examples include Charles Foster's Being a Beast (Foster 2016) and Daniel Chamovitz's What a Plant Knows (Chamovitz 2012). These forms of wild performativity need not be bound by the epistemic norms of field science, but can include more playful, fantastical or disconcerting techniques for recalibrating human senses and perceptions of the wild (H. Lorimer 2006; Dewsbury and Naylor 2002).

A second version of wild performativity involves a deliberate attempt to interact with nonhuman species, processes, or forces. The aim here is to go beyond the representational imperatives of fieldwork to establish reciprocal relationships with nonhuman creatures in 
the field. While some natural scientists are coy about how their presence shapes the phenomena they are observing (observation effects are understood to compromise the objectivity of their data), others are more willing to place their bodies in the field as generative mechanisms for encounters with the wild (Despret 2013). For example, the sheep ethologist Thelma Rowell or the primatologist Barbara Smuts emphasise the importance of interspecies 'politeness' in their field studies (Haraway 2008). Here, an attention to the social norms of animal behavior opens enquiry to a range of interesting questions. The same is true for hunters, shepherds, foragers, gardeners and foresters, whose successful pursuit of their target organism often involves communication across species boundaries (Lorimer 2006; Ingold 2000; Kohn 2013). Meanwhile, artist-researchers have explored the possibility of reciprocal encounters with more obtuse entities, like rocks and the weather (Hopfinger 2015); as well as considering the ways in which we are performed by ecologies (Kershaw 2016). These forms of wild performativity have an open-ended and dialogical character, they seek to generate surprises of detailed affordance and entanglement, rather than prove hypotheses. In so doing they engage scientists and other experts in forms of experimentation more akin to those pursued by artists (J. Lorimer and Driessen 2014).

A third version of wild performativity might explore the analytical potential of concepts from performance studies and cognate fields for making sense of the ecological and geomorphological dynamics of a field site. Work in multispecies ethnography has begun to explore the conceptual overlaps between ethology and ethnography (Lestel, Brunois, and Gaunet 2006; Kirksey and Helmreich 2010). Enthusiasts suggest that concepts and techniques for attending to the somatic and affective dimensions of human life might enhance our understandings of animal behavior, and vice-versa (Lorimer, Hodgetts, and Barua 2018). Likewise, there is an emerging interest in how established approaches to choreography and musicology might help us understand the situation and temporal dimensions of ecology (Tsing 2015). Concepts (and metaphors) such as rhythm, harmony, melody, and counterpoint can be applied to understand diurnal, seasonal and more protracted landscape dynamics. Similarly, the multispecies interactions inherent to any functional ecology might also be newly recoded through the evolving lexicon of environmental performance studies.

In the analysis that follows, this article focusses on several events that were created during the workshop at Knepp. These help to illustrate the different dimensions of the concept of wild performativity and indicate paths for future explorations. They also reveal the 
limitations of our experiments so far. We are developing a complex practice involving intervention, response and representation. These wild performatives may not escape citation, and have yet to significantly impact on individual or ecological identities. However, we contend that they offer many rich and productive opportunities for recoding our relationship with wildness. In examining these wild performatives, our aim is to prompt further dialogue on rewilding in the geohumanities - especially at the intersections of cultural geography and performance studies - and to chart the early stages of a new research project.

\section{Rewilding Knepp}

The importance of Knepp to the rewilding movement is significant. In the UK, it is the only example of relatively large-scale (1400 ha) rewilding in a lowland context. Burrell is the Chair of Rewilding Britain; an organisation established in 2015 to 'demonstrate a model for rewilding that works at a scale new to Britain' (Rewilding Britain, online). The Estate serves as a platform to showcase rewilding and Burrell regularly hosts national and international delegations. The Knepp project is exemplary of the range of positive outcomes for

biodiversity that rewilding can bring about, many of which may be unexpected. The easing of agricultural pressure and the shift to 'naturalistic' modes of herbivore management has given Knepp the only recovering population of turtle doves in the UK and made the site home to 32 species of butterflies, including the purple emperor (Stares 2016). A major cause of these healthy populations is the grazing, trampling and rooting behaviour of the animals, as well as the transferral of seeds and nutrients across the landscape through the action of dunging, which allows key plant species to thrive, and provides a food source for various species. For example, Tamworth pigs churn up the soil in search of roots and worms, so that common sallow can grow, which provides food to the purple emperors. Such ecological 'cascades' are key to the appeal of rewilding. They help explain why the movement has developed a committed and even evangelistic following in recent years.

George Monbiot stresses the importance of imagination and creativity to the rewilding project, proposing that we ask ourselves 'Why not?' (Monbiot 2013). This is a question that has been answered emphatically by opponents. Amongst scientists, Tim Caro and Paul Sherman summarise a range of objections, including 'adverse effects of alien species on the ecosystems they are meant to foster; importation of diseases that may leap to native species; escapes that lead to hybridization; and predators jumping fences to endanger livestock' (Caro 
and Sherman 2009, 985). For agriculturalists, Nick Harvey refers to 'worries about the erasure of ancient and important cultures such as upland sheep farming in Wales' (Harvey, 2016). These concerns are not trivial, and need to be taken seriously by those committed to building a rewilding movement in Britain. Proponents of the concept - including Monbiot recognise this, cautioning that 'rewilding must be constantly questioned and challenged [and] never be used as an instrument of expropriation or dispossession' (Monbiot 2013, 12). Rewilding takes place in contested, challenging contexts and it has to be carefully and sensitively advanced.

For its supporters, at a time of consistent species decline, when public concern for the environment appears to be floundering (Wikes 2016; Globescan 2013), rewilding offers an imaginative vision of a future in which wildness has a place. But in order for wildness to coexist with and become integrated within human civilisation, it is necessary to manage its processes, monitor its impacts, and police its boundaries (Lorimer and Driessen 2014). Knepp is a complicated site in which human plans, policies and procedures frame and determine its natural processes. Tensions play out between managed and unruly behaviours, and there is a perpetual negotiation between enclosure and exclosure, borders and openness. Our wager was that in this complex, multiple landscape, artistic intervention might reveal, complicate, or challenge some of these dynamics.

\section{Wild Performative 1: Anomalous Big Cats}

On the first morning, two concurrent journeys took place with groups swapping over half way: a safari tour of the Estate led by Knepp's ecologist in an open-sided Pinzgauer (an Austrian Troop Carrier); and a 'misguided' tour of the area around the camp site led by walking artist-scholar Phil Smith. Smith facilitated a creative and playful engagement with the site that repurposed some of his strategies for the 'counter-tourism' of heritage sites (Smith 2013). As we gathered at the edge of the woodland bordering the campsite, looking out over a field, Smith suggested that reported sightings of Anomalous Big Cats (ABCs) may hint at a suppressed human wildness. In his 2005 performance text, Crab Steps Aside, Smith ruminates on $\mathrm{ABCs}$ as he arrives at a field in the Devon village of Newton St Cyres:

Some people think there are all sorts of big cats - pumas, panthers... even lions and tigers - loose in the English countryside: the beast of Bodmin, the 
Lion of South Brent... prehistoric survivors, released by private owners or lost by zoos...

But there is another theory - that what we see isn't there...but WAS. And the imprint is still in our minds. We see some shape: a shadow among the leaves... and a very old, genetic memory [Flick open fingers by the side of head] lights up...

Of sloping haunches and a long toothed grin, of a loping walk and blazing eyes $-\mathrm{a}$ beast that hunted our ancestors... and then died.

(Smith 2009, 127-128)

This phenomenon is also explored by Monbiot, who suggests that these sightings may arise from the vestiges of past, wilder lives. Monbiot wishes to ground these in 'evolutionary memories of conflict and survival, memories which must incorporate encounters - possibly the most challenging encounters our ancestors faced - with large predatory cats' (Monbiot $2013,60)$. We are less convinced by this appeal to a primal reflex, aware of the violence it has been used to legitimate (Driessen and J. Lorimer 2016).

During our walk, Smith encouraged us to train our peripheral vision to search for ABCs. We scanned the landscape, attuning to the shapes and textures that may trigger our instinctive response to predators. Immediately, we recalled our first visit to Knepp in July and the state of anticipation as we walked into the Estate in search of the animals and become lost on a wet and murky Spring day. At every corner, we expected to encounter something wild and unpredictable. Today, in autumnal sunlight our eyes traced the treeline at the far end of the field and we were surprised by the sudden appearance of one of the participants - the artist Antony Lyons - assuming a catlike pose half way up a tree.

Insert Figure 2: Antony Lyons performs an $\mathrm{ABC}$

This was an amusing and irreverent intervention, but it confronted the spectators with the fallacy of rewilding: that the animals are somehow there for our benefit, to serve our human project rather than being part of it as collaborators; and also to remind us that we may be looking at it with unseeing eyes. It was a valuable warning to remain cognisant of our own values and agendas as we encountered, and attempted to collaborate with the site's nonhuman 'performers'. And in its wry cautioning against anthropocentrism, it prepared us for the interactions with Knepp's wildlife that were soon to follow. 


\section{Wild Performative 2: The Stag}

For anyone who has read Jacques Derrida's The Animal That Therefore I Am, it is difficult to stand in the presence of a silent, observing animal, without reflecting on the discomfort, or shame, of meeting the 'insistent gaze of the animal' (Derrida 2008, 4). So it was when the safari vehicle paused on its way to the crane enclosure to enjoy the majesty of one of the nosiest animals on the site (we were there in the middle of the red deer rutting season and most of us had been kept awake by the primal roars of the stags late into the night). While Derrida stood naked in front of his housecat, we were fully clothed in a military vehicle. This unavoidably anthropocentric approach enforced separation and distance. Nonetheless, the 'naïve assurance of man' (and woman) was felt by all, and we confronted an inability to know if the stag's gaze could respond to our presence, or merely react (Derrida 2008, 6, 8-9).

\section{Insert Figure 3: a stag at Knepp Castle Estate}

This encounter mobilised the tensions involved in the distinction between response and reaction, resulting from the seeming unknowability of the nonhuman actor to us in this alien moment. In a traditional (interhuman) performative exchange, it is possible to ascertain the 'success' or 'failure' of an utterance (or the 'felicity' or 'infelicity' in Austin's terms). The ability to judge the outcome of an Austinian speech act is predicated on a shared frame of reference, in this case linguistic. This was not possible for us in this wild context without an anthropocentric imposition of meaning. We were prevented from giving ourselves over to the wildness of this moment by our encasement within layers of human-made materials, so there was no real mutuality in this exchange. Moreover, we lacked the prior experience of the rhythms of deer and their forested landscapes found amongst hunters, ethologists, and other natural historians. Such experts have learnt to be affected by animals like deer. Some have developed 'polite' (after Haraway 2008) means of initiating reciprocal encounters across species boundaries (H. Lorimer 2006). Our encounter with the stag was not founded on such familiarity. Framed by the earlier presence of the catman it instead offered a provocation to creative experiment. The stag confronted us with our inability to understand or experience this encounter from anywhere other than a human situation, and with anything other than a human frame of reference. 'What will you do with this?' it seemed to demand, and for the next few hours, this question wanted an answer. 
Following a picnic lunch, we returned to the converted cowbarn that served as our main working space, for a workshop led by performance maker Karen Christopher. This session started with us creating short individual performances in response to a significant moment in the day so far. Overend's choice was to attempt to capture something of the distance we experienced in our brief encounter with the stag. The workshop gradually 'tangled' our performance work together to create group performances that became aggregates of our individual responses (Bottoms 1998). The group went to a communal space bordering a field and used the perspective that this location afforded to offset our human activity with a remote wild presence.

Insert Figures 4 and 5: Alun Lewis in the foreground, and David Overend 'being a stag'

This performance embraced its inadequacy to respond to the wildness of the stag. Overend simply sat on a chair 20 metres away from the other participants (about the same distance that the stag was from our group), and looked back. This was his attempt to 'be' a stag in the context of a 'tangled' group performance, and it was consciously striving for an impossible state of being. This was the inevitable failure of representation - a double failure for Sara Jane Bailes, as artistic activity not only responds to a perceived failure in the present (the 'problem' offered by the stag); it can also never succeed to 'be the thing it wishes to communicate' (Bailes 2010, 11). While the notion that representational theatre strives to be anything other than a metaphorical system has been contested (Rebellato 2009), a conscious acknowledgement of the discrepancy - between the act of performance and that which it signifies - can be used in productive and enlightening ways. For Dee Heddon, performance is a 'contingent and relational act which takes place inside a thick, lively and complex matrix of interconnected actants' (Heddon 2016, 336). Within the 'matrix' of rewilding - our ecological assemblage - with its unique relationships between human and nonhuman 'actants', it is important to recognise the limitations of performance as an interventional practice. However, in another example of becoming-stag, Baz Kershaw worked with an antler-like formation in the adjacent woodland to create a different sort of wild performative which was not so bound by the limitations of representation.

Insert Figure 6: Baz Kershaw's stag-like intervention 
In her response to this moment, Sarah Hopfinger identified 'a performance of attentiveness', which was 'not merely mine nor the 'antler man's' but seems to be an attentiveness that belongs to the ecology of here, of bodies-stillness-sticks-watchers-wood-wind-airperformers-and-more' (Hopfinger 2018). Unlike Overend's response to distance and unrelatability, Kerhaw's intervention 'opened up a mode of attention - of attending - that is somehow slow, soft, curious, surprising, vulnerable, alert, and, perhaps, wild'. As Kershaw's action and Hopfinger's response suggest, despite their limitations, wild performatives also have generative potential to affect the ways we attend to our natural environment. This was taken up later in the workshop as some of the participants aimed for a greater reciprocity in their performances.

\section{Wild Performative 3: Acorn Duets}

The nocturnal cacophony that kept so many of us awake and in a state of enforced attentiveness to our environment was comprised of many things:

Insert Figure 7: detail from one of Helen Billinghurst's 'thought maps' of the event (Making Routes, online)

The 'popping and plopping' acorns fell constantly, both into the pond between the campsite and the cowbarn, where we held the workshop, and onto the corrugated steel roof of the 'go down', or camp site kitchen. They provided a constant soundtrack to our workshop, at times jarring and jolting but gradually blending into the milieu of familiar natural sounds until they became reassuring and even restful. The acorns directly impacted on our work at Knepp, and as such might be understood as 'wilful agents' in the environment (Hopfinger 2015, 143). Recognising performative agency in such 'non-human materialities' recalls Carl Lavery's discussion of what theatre 'does' in ecological terms: 'its dramaturgical distribution of organic and inorganic bodies in actual time and space creates sensations and experiences in the here and now' (Lavery 2016, 230). Receptive to the rhythms and melodic countenance of Knepp's natural phenomena, our aim was to utilise performance making techniques to establish a productive exchange with nonhuman actors.

During Christopher's workshop, three participants, working independently, made similar performances, which involved duets with the falling acorns: Laura Bissell and Jamie Lorimer 
responded to the 'plopping' into the pond, and Filipa Soares worked with the regular mechanical pounding of acorns hitting a metal roof, which had been particularly notable to her at night, as one of the occupants of the tent closest to this structure. In a later group performance, Bissell and Soares combined their approach to create an acorn duet on the roof, each taking a position on either side of the go down so that it was never clear which of the sounds were caused by the human performers, and which were occurring naturally.

Insert Figure 8: Laura Bissell performs an 'acorn duet'.

This duet - which might more accurately be called a trio with the adjacent oak tree - was a co-performance with the acorns. It built from a simple action and became conversational: when an acorn fell hit the roof, one of the performers would throw another acorn up in response. This piece made use of the obscured sightlines provided by the architecture of the human-made structure, in order to hide the origin of each acorn's trajectory. Fall became indistinguishable from throw, and offer from response. The simplicity of the action instigated a complex ecology of 'interconnected actants' within the 'matrix' of the performance. As such, this acorn duet seemed to bring human and non-human actions into a productive relationship. This is another example of how the methods and methodologies of performance might inform an approach to rewilding. While Christopher's strategy of entanglement created group performances that referenced multiple aspects of our experiences at Knepp, this simple action provided a microcosm of our work over the course of the two days. This was a percussive dance between an initiating oak tree and responsive humans, between chance and intention. It was a dance of rewilding.

\section{Conclusion}

Over two days, our group explored rewilding from a range of perspectives, creatively experimenting with the processes and participants of the Wildland Project at Knepp. The walks and workshops led by Smith and Christopher established a playful, creative and artistically framed relationship with the site, which emerged in dialogue with scientific and ecological presentations and journeys. At the end of the event, we came together to reflect on the efficacy of our collaboration, identifying key themes and research questions that will guide the next phase of the project. 
Instigating, experimenting, and subsequently reporting on some of the wild performatives that took place during the event, has been an opportunity to consolidate and 'map out' the key areas of enquiry: First, looking for anomalous big cats reminded us of our anthropocentric position in relation to the site. While Monbiot warns of conserving nature at the expense of the people who inhabit its sites, and shows how rewilding can benefit people, it is also important to recognise the agendas and assumptions that we bring to these places. Second, our encounter with the stag, and Overend's subsequent attempt to somehow be that animal, in the context of a performance piece, highlights the fallibility of performance. We know the limitations of our response to wildness, and we do not know - perhaps cannot know - the nature of the stag's response to us. As an alternative version of this performance, Kershaw's stag-performance suggested the potential for wild performatives to generate an ecological attentiveness. Third, the acorns that fell throughout our stay at Knepp simultaneously presented and prompted a performative action. The acorn duets suggested a model for human and non-human collaboration that will continue to be developed.

Over the coming months, we will be leading further events, including a guided tour round sites in central London, where elephants and hippopotamuses once roamed (Schreve and Juby 2008). As we continue to work together, developing our transdisciplinary approach and finding the right languages and methods that help us to think and practice together, we are looking to features of rewilding. Rewilding offers an unpredictable and unruly model of conservation that can guide and inform our approach to academic collaboration and knowledge exchange.

Thanks to Sir Charles Burrell and Isabella Tree, Penny Green and all the staff at Knepp, and to the workshop participants: Helen Billinghurst, Laura Bissell, Karen Christopher, Harriet Hawkins, Sarah Hopfinger, Baz Kershaw, Alun Lewis, Antony Lyons, Chris Sandom, Danielle Schreve, Caitlin de Silvey, Phil Smith, Filipa Soares and Sam Turvey.

This research was supported by the University of Oxford's School of Geography and the Environment Inspiration Award; and Royal Holloway, University of London's Humanities and Arts Research Institute's Fellowship Scheme. 


\section{References}

Austin, J.L. 1962. How to do Things with Words. (Oxford University Press: Oxford).

Bailes, S.J. 2010. Performance, Theatre and the poetics of Failure. London: Routledge.

Bottoms, S. 1998. 'The Tangled Flora of Goat Island', Theatre Journal, 50: 421-446.

Butler, J. 1990 'Performative Acts and Gender Constitution: an essay in Phenomenology and

Feminist Theory', Performing Feminisms: Feminist critical theory and theatre. ed.

Sue-Ellen Case. (Johns Hopkins UP, Baltimore).

Caro, T. and Sherman, P. 2009. 'Rewilding Can Cause Rather Than Solve Ecological

Problems'. Nature, 462 (24/31): 985.

Chamovitz, D. 2012. What a Plant Knows (Oneworld Publications: Oxford).

Derrida, J. 1972. 'Signature Event Context', Limited Inc. (Northwestern University Press:

Evanston, IL): 1-24.

Derrida, J. 2008. The Animal That Therefore I Am. (Fordham University Press: New York).

Despret, V. 2004. 'The Body We Care For: Figures of Anthropo-Zoo-Genesis', Body \& Society, 10: 111-34.

Despret, V. 2013. 'Responding Bodies and Partial Affinities in Human-Animal Worlds', Theory, Culture \& Society, 30: 51-76.

Dewsbury, J. D., and S. Naylor. 2002. 'Practising geographical knowledge: fields, bodies and dissemination', Area, 34: 253-60.

Dolan, J. 2001. 'Geographies of Learning: Theater Studies, Performance, and the "Performative"', Geographies of Learning: theory and practice, activism and performance (Wesleyan University Press: Middletown, CT). 65-91.

Driessen, C. and Lorimer, J. 2016. 'Back-breeding the aurochs: the Heck brothers, National Socialism and imagined geographies for nonhuman Lebensraum.' in P. Giaccaria and C. Minca (eds.), Hitler's Geographies: The spatialities of the Third Reich. (University of Chicago Press: Chicago).

Foster, C. 2016. Being a Beast (Profile Books: London).

Globescan. 2013. 'Environmental Concerns "At Record Lows": Global Poll'. www.globescan.com/news-and-analysis/press-releases/press-releases-2013/261environmental-concerns-at-record-lows-global-poll.html. (accessed 12/10/17).

Haraway, Donna Jeanne. 2008. When species meet (University of Minnesota Press: Minneapolis).

Harvey, N. 2016. 'Radical Rewilding'. Action for Conservation. actionforconservation.org/single-post/2016/03/08/Radical-Rewilding. (accessed 12/10/18).

Heddon, D. 2016. 'Confounding Ecospectations: disappointment and hope in the forest'. Green Letters: Studies in Ecocriticism 20 (3): 324-339

Hopfinger, S. 2015. 'Wilding Performance', Performing Ethos, 5: 137-144

Hopfinger, S. 2018. 'A Creative Document of Performing Wild Geographies, 2nd - 4th October 2017, Knepp Estate' [blog post]. makingroutes.ning.com/profiles/blogs/acreative-document-of-performing-wild-geographies-2nd- $4^{\text {th }}$ (accessed 14/03/18).

Ingold, Tim. 2000. The perception of the environment: essays on livelihood, dwelling and skill (Routledge: London). 
Kershaw, B. 2016. 'Projecting Climate Scenarios, Landscaping Nature, and Knowing Performance: on becoming performed by ecology', Green Letters 20 (3): 270-289.

Kirksey, S. E., and S. Helmreich. 2010. 'The Emergence of Multispecies Ethnography', Cultural Anthropology, 25: 545-76.

Knepp Wildland. 'Grazing Ecology'. knepp.co.uk/the-inspiration (accessed 12/10/17).

Kohn, E. 2013. How Forests Think: Toward an Anthropology Beyond the Human (University of California Press: Berkeley).

Lavery, C. 2016. 'Introduction: performance and ecology - what can theatre do?', Green Letters, 20 (3): 229-236.

Lestel, D., F. Brunois, and F. Gaunet. 2006. 'Etho-ethnology and ethno-ethology', Social Science Information, 45: 155-77.

Lorimer, H. 2006. 'Herding memories of humans and animals', Environment and Planning DSociety \& Space, 24: 497-518.

Lorimer, J. 2008. 'Counting corncrakes: The affective science of the UK corncrake census', Social Studies of Science, 38: 377-405.

Lorimer, J, and Clemens Driessen. 2014. 'Wild experiments at the Oostvaardersplassen: rethinking environmentalism in the Anthropocene', Transactions of the Institute of British Geographers: 169-81.

Lorimer, J., Hodgetts, T. and Barua, M. 2017. 'Animals' atmospheres', Progress in Human Geography.

Lorimer, J., Sandom, C. Jepson, P., Doughty, C., Barua, M., and Kirby, K. J.. 2015. 'Rewilding: Science, Practice, and Politics', Annual Review of Environment and Resources, 40: 3962.

Madison, S. and Hamera, J. The SAGE Book of Performance Studies. (SAGE: London).

Making Routes, 'Helen Billinghurst's Sketches and Maps' [blog post]. makingroutes.ning.com/profiles/blogs/helen-billinghurst-s-sketches-and-maps. 2017. (accessed 12/10/17).

Monbiot, G. 2013. Feral: Searching for enchantment on the frontiers of rewilding (Penguin Books Limited).

Pearson, M. and Shanks, M. 2001. Theatre/Archaeology (Routledge: London)

Rebellato, D. 2009. 'When We Talk of Horses: or, what do we see when we see a play?', Performance Research 14 (1): 17-28

Rewilding Britain. 'Our Work' . rewildingbritain.org.uk/our-work (accessed 12/10/17).

Schreve, D and Juby, C. 2008. 'The Thames Valley'. London: The Illustrated History. ed. C Ross and C John (Allen Lane: London): 20-21.

Smith, P. 2009. 'Crab Steps Aside'. Walking, Writing and Performance: autobiographical texts by Deirdre Heddon, Carl Lavery and Phil Smith. ed. Roberta Mock (Intellect: Bristol): 115-140.

Smith, P. 2013. Countertourism: the handbook. (Triarchy Press: Devon)

Stares, C. 2016. 'Purple emperor is the jewel of the wildland', The Guardian, https://www.theguardian.com/environment/2016/aug/12/purple-emperor-jewelwildland-butterfly-country-diary (accessed 11/01/18).

Svenning, J-C., Pedersen, P. B. M, Donlan, C. J., Ejrnæs, R., Faurby, S., Galetti, M., Hansen, D. M., Sandel, B., Sandom, C. J., Terborgh, J. W., and Vera, F. W. M.. 2016. 'Science for a wilder Anthropocene: Synthesis and future directions for trophic rewilding research', Proceedings of the National Academy of Sciences, 113: 898-906.

Thrift, N. 2007. Non-Representational Theory: space, politics, affect. (Routledge: London). 
Tsing, A. L. 2015. The Mushroom at the End of the World: On the Possibility of Life in Capitalist Ruins (Princeton University Press).

Vera, F. 2000. Grazing ecology and forest history (CABI: Wallingford).

Von Hantelmann, D. 2010. How to do Things with Art (JRP/Ringier: Zurich).

Wikes, R. 2016. 'What the world thinks about climate change in 7 charts'. Pew Research

Centre. www.pewresearch.org/fact-tank/2016/04/18/what-the-world-thinks-aboutclimate-change-in-7-charts/ (accessed 14/03/18). 